\title{
Effects of simultaneous exposure to noise and styrene on rat liver enzymes
}

\author{
Tehrani M, BSc ${ }^{1}$, Khavanin A, $\mathrm{PhD}^{2 *}$, Asilian $\mathrm{H}, \mathrm{PhD}^{2}$ \\ 1- MSc Student of Occupational Health, Dept. of Occupational Health Engineering, Tarbiat Modares University, Tehrani, \\ Iran. 2- Associate Prof, Dept. of Occupational Health Engineering, Faculty of Medical Sciences, Tarbiat Modares \\ University, Tehran, Iran.
}

\begin{abstract}
Received: December 2016, Accepted: April 2017

Background: Liver is an important organ that responsible for biological detoxification. There are few studies about the effect of co-exposure to organic solvents and noise on hepatic system enzymes. The study aim was to assess the effects of short-term exposure to noise and styrene on rat liver enzymes.

Materials and Methods: In this experimental study, we studied the liver enzymes of male rats. Twenty-four rats $(250 \pm 10 \mathrm{~g})$ were divided in four groups $(\mathrm{N}=6)$ : control $(\mathrm{A})$, noise exposure $(100 \mathrm{~dB})$ $(B)$, styrene exposure $(750 \mathrm{ppm})(\mathrm{C})$, styrene $(750 \mathrm{ppm})+$ noise $(100 \mathrm{~dB})$ co-exposure $(\mathrm{D})$. Treatment was performed in an 8 hours/day and 5 day/week order for 2 weeks. Blood samples were obtained for AST, ALT, and ALP investigation. Data analysis was performed in SPSS software.

Results: Calculations based on weighting did not show any significant difference in body weight and liver/body weight ratio in co-exposed group, compared to the control $(\mathrm{P}>0.050)$. Noise exposure caused a statistically significant increase both in liver enzymes (ALT, ATP, AST) $(\mathrm{P}<0.050)$ and liver/body weight ratio compere to control. The mean serum ALP \& ALT level in the co-exposure group was significantly higher than control $(\mathrm{P}<0.001)$. Our findings indicated that acute styrene inhalation did not significantly change liver enzymes (AST, ALT) compared to control group (P> $0.050)$.

Conclusions: It can be concluded that exposure to noise (100 dB) alone and combined with styrene can cause imbalance in liver enzymes level. Results suggest that liver enzymes are sensitive to noise therefore can be used as a screening method for early diagnosis of hepatic dysfunction for exposed individuals at work places. The current study clearly confirmed that co-exposure to noise and styrene has an additive effect in ALP augmentation.
\end{abstract}

Keywords: Noise, Styrene, Liver Enzymes, Blood, Rat

\section{Introduction}

Noise is pervasive in everyday life and can cause both auditory and non-auditory health effects (1). Evolution has programmed human beings to be aware of sounds as possible sources of danger (2). Noise, defined as unwanted sound and a pollutant has adverse effects on health which have been neglected. Often negative health outcomes of high levels of noise can be seen in chronic exposures. Annually, about 22 million US workers and more than 600 million of world work force are exposed to hazardous noise levels at work (1, $3)$. Today noise is one of the most common physical occupational hazards (4). Several studies on noise and health has revealed that in addition to hearing defects, noise can cause hypertension and cardiac arrhythmias (5). Similar to possible effects of some other electromagnetic waves, noise can distort antioxidant balance through the mechanism of producing free radicals and as a source of oxidative stress, this creates the possibility of the development of many diseases, including cancer $(6,7)$. In Dehghani et al. study which rats were exposed to noise $(100 \mathrm{~dB}, 700-5700$ $\mathrm{Hz}, 8$ hours/day, 14 days), increase in

* Corresponding author: Ali Khavanin, Dept. of Occupational Health Engineering, Faculty of Medical Sciences, Tarbiat Modares University, Tehran, Iran. E-mail: Khavanin@modares.ac.ir 
oxidation metabolites and decrease in liver antioxidants was reported (8). A study on effects of high frequency noise indicated that exposure to noise could lead to pathological changes in liver (9). Also, a major source of styrene is occupational exposure as styrene is used in industry to manufacture many plastics, resins and synthetic rubbers, and as solvent for unsaturated polyester resins, cleaning up and maintenance procedures $(10,11)$. During production and consumption styrene evaporate and spread in air due to high volatility. Styrene can be released into environment through cigarette smoke, exhaust emission from motor vehicles and during combustion or heating of styrene-containing polymers and some organic materials. Benzene, toluene, xylene and styrene are among the most highly used aromatic solvents and the most important industrial solvents used in the production of dyes, adhesives and pesticides (12). A significant amount ( $90 \%)$ of styrene absorbed by humans undergoes hepatic oxidation by cytochrome P450 (10, 11). Some recent studies have shown a positive association between exposure to halogenated solvents and fatty liver disease (13). However, there are few studies about the association between exposure to aromatic solvents and hepatic toxicity (12). According to the Clean Air Act Amendments (CAAA) of 1990, styrene has been classified as one of 189 hazardous and toxic air pollutants due to its adverse effects on human health (14). The International Agency for Research on Cancer (IARC) has evaluated styrene as possibly carcinogenic to humans (group 2B) $(3,15,16)$. However, it is not known whether this may be due to styrene alone, or concurrent exposure to additional chemicals in the working environment. The 4hour LC50 for styrene inhalation is 2700 $\mathrm{mg} \cdot \mathrm{m}^{-3}$ (634 ppm) in rats (equating to an LCt50 of $\left.11.25 \mathrm{mg} \cdot \mathrm{min}^{-1} \cdot \mathrm{m}^{-3}\right)(10,11)$. Coexposure to different physical and chemical factors could potentially provoke different responses in health. The main cause of occupational poisoning is active and super active interactions by multiple exposures to mixture of chemicals which has greater effect than each factor alone (17), Co-exposure to styrene vapor and noise pollution in some workplaces is an example. According to researches, tissue damage is probable with exposure to high levels of noise combined with hazardous organic solvents like styrene $(18,19)$.

Today many workers are exposed to different physical and chemical pollutants, and few studies have been performed to show the association between co-exposure to noisestyrene and hepatic toxicity. Therefore, we decided to design a study to assess this relationship and evaluate the predictive value of screening hepatic injury by measuring serum levels of liver enzymes in rats exposed to noise and styrene.

\section{Material and Methods}

Twenty-four albino Wistar male rats $(250 \pm 10$ g) were purchased from Pasteur Research Institute (Tehran, Iran) in April 2016 and were divided into 4 groups $(n=6)$. For the purpose of adaptation, animals were kept in animal house of Tarbiat Modares university, Iran, for a week. Rats were kept in normal cycle (12 hours light: 12 hours dark) and temperature and relative humidity were set to $22-24^{\circ} \mathrm{C}$ and $55 \%$ respectively (20). Unrestricted access to food (commercial chow) and water was provided for animals. The project was approved by the Medical Ethics Committee of Medical Faculty of Tarbiat Modares University and all efforts were made to minimize the number of animals used and their suffering. All animals were weighed at the first and last day of exposure by the Pand digital scale (model PX6000) with $0.1 \mathrm{~g}$ accuracy.

Animals were treated over a sub-acute exposure period for 2 weeks ( 5 day/week and 8 hours/day from 8 a.m. to 4 p.m.) (21). DPOAE test as audiometry was done for all animals after study, by OAE ILO88, HORT MANN device, and audible and healthy rats were chosen. Four groups received exposure 
as follows: control (A), white noise (100 dB) (B), styrene (750 ppm) (C), and white noise $(100 \mathrm{~dB})$ and styrene (750 ppm) (22) simultaneously (D). Each rat were place in separate small cages during exposure in the chamber $(80 \times 30 \times 40$ centimeter in dimension) and nothing as food or water were available to prevent natural behavior of piling. Enough space for each rat and appropriate air and contaminants (noise and styrene) distribution was provided in the chamber. Styrene vapor concentration and noise level were adjustable. Top and bottom hopper were designed for uniform distribution of polluted air during exposure, and also to collect animal waste conveniently. Enclosures and the door were fully insulated to prevent leakage of contaminants. White noise was played with cool edit software, through 2 speakers $(1 \mathrm{~W}, 8$ ' $\Omega$ ) installed at the top of the chamber. During the exposure, noise uniformity was monitored regularly at 4 points, using calibrated $B$ and $\mathrm{K}$ noise meter device (model 2238). Styrene vapor entered from concentration and mixing box by hosing and was checked constantly every 20 minutes by Phocheck (model 5000, U.K.) and was adjusted in desired concentration by ventilation fan volume installed at the below hopper. Air circulation was about 10 times per hour. The outlet was directed under a laboratory hood by a flexi duct and exited through the waste collector (figure 1). The day after ending exposure (10 a.m. to 2 p.m.) animals were anesthetized by intraperitoneal injection of ketamine (40 $\mathrm{mg} / \mathrm{kg}$ body weight) and xylazine $(10 \mathrm{mg} / \mathrm{kg}$ body weight) (23), weighed, and then blood samples $(4 \mathrm{ml})$ were obtained using cardiac puncture method. In the final step, liver was extracted and weighed. Blood sample was centrifuged (model PIT320R, $1000 \mathrm{xg}$ ) for 10 minutes to prepare serum sample (24). Alanine aminotransferase (ALT), aspartate aminotransferase (AST) and alkaline phosphatase (ALP) levels were determined by an autoanalyzer (904-Hittachi, Japan) using commercial kits (Pars Azmon, Iran). The normality of data were examined using $\mathrm{K}-\mathrm{S}$ test, and the results were analyzed by ANOVA and Dunnet test in SPSS software (version 21.0, IBM Corporation, Armonk, NY, USA). Significance level of the test was considered less than 0.05 .

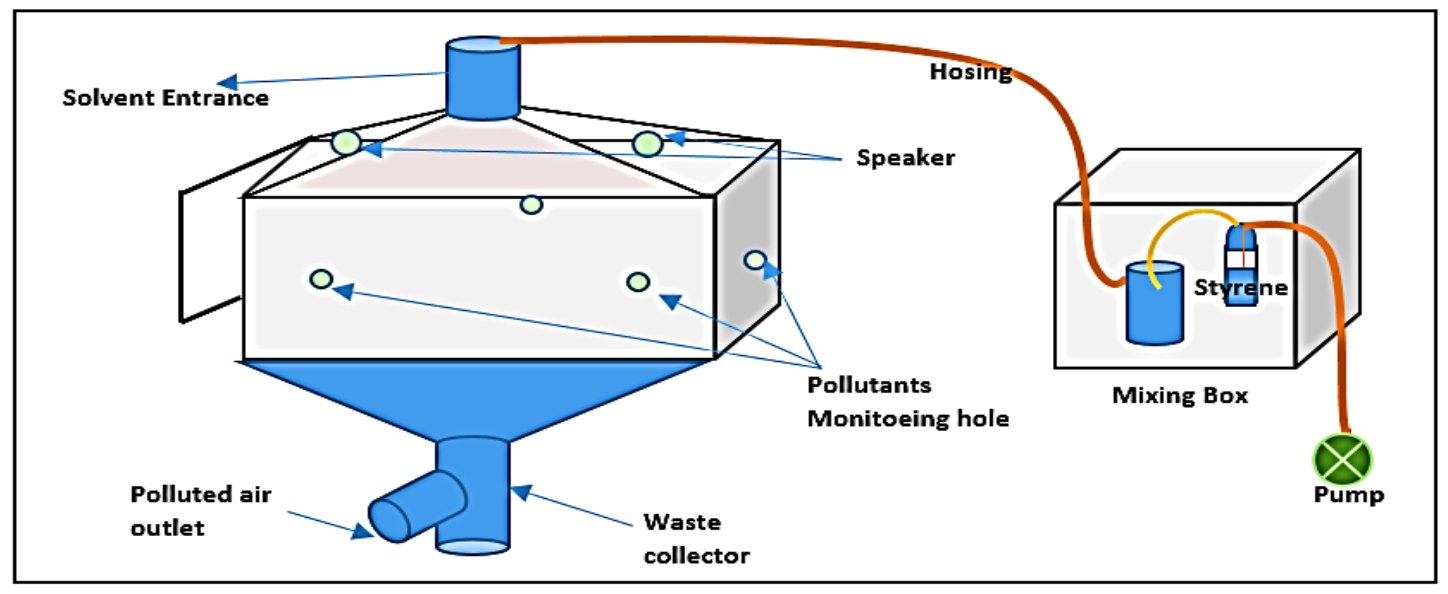

Figure 1: Mixing box of styrene and exposure chamber

\section{Result}

Results of measuring rats and their liver tissue weight: In present study, weight of rats and their livers were measured in all groups.
As seen in table 1 , mean weight before and after exposure did not show significant difference $(\mathrm{P}>0.050)$ between control and exposure groups based on one-way ANOVA 
descriptive test, but liver/body weight ratio in noise group compared to control group showed a significant reduction $(\mathrm{P}<0.050$,
Table 1); however, it did not show any significant difference in other exposure groups $(\mathrm{P}>0.050)$.

Table 1: Initial weight, final weight, liver weight and liver/body weight ratio of rats in different groups

\begin{tabular}{|c|c|c|c|c|c|}
\hline \multirow{2}{*}{ Variable } & \multicolumn{5}{|c|}{ Groups } \\
\hline & & $\mathbf{A}$ & B & $\mathbf{C}$ & D \\
\hline \multirow{2}{*}{ Initial weight (g) } & Mean \pm SD & $225.0 \pm 8.7$ & $270.0 \pm 7.9$ & $260.0 \pm 33.7$ & $247.5 \pm 9.6$ \\
\hline & $\mathrm{P}$ & - & 1 & 1 & 0.905 \\
\hline \multirow{2}{*}{ Final weight (g) } & Mean \pm SD & $250 \pm 5$ & $294.0 \pm 10.8$ & $288.8 \pm 37.5$ & $272.5 \pm 9.6$ \\
\hline & $\mathrm{P}$ & - & 0.927 & 0.994 & 0.905 \\
\hline \multirow{2}{*}{ Liver weight (g) } & Mean \pm SD & $12.84 \pm 0.26$ & $12.7 \pm 1.6$ & $13.33 \pm 1.63$ & $13.97 \pm 0.36$ \\
\hline & $\mathrm{P}$ & - & 0.673 & 0.908 & 0.998 \\
\hline \multirow{2}{*}{$\begin{array}{c}\text { Liver/body weight } \\
\text { ratio }\end{array}$} & Mean \pm SD & $0.05 \pm 0.09$ & $0.04 * \pm 3.71$ & $0.05 \pm 1.44$ & $0.05 \pm 0.48$ \\
\hline & $\mathrm{P}$ & - & 0.023 & 0.084 & 1 \\
\hline
\end{tabular}

* The mean difference is significant at the 0.05 level.

Results of measuring serum AST, ALT, ALP: According to table 2, ALP and ALT levels of co-exposure and noise groups showed significant increase comparing to control group $(\mathrm{P}<0.050)$ but just noise group showed significant increase in AST level $(\mathrm{P}<$ $0.050)$. It must be noted that styrene exposure could just affect ALP $(\mathrm{P}<0.050)$.

Table 2: Mean \pm SD and P-value measures of AST, ALT and ALP of blood serum of group under study $(\mathrm{N}=6)$

\begin{tabular}{|c|c|c|c|c|c|}
\hline \multirow{2}{*}{ Variable } & \multicolumn{5}{|c|}{ Groups } \\
\hline & & $\mathbf{A}$ & B & $\mathbf{C}$ & D \\
\hline \multirow{2}{*}{ AST (U/l) } & Mean \pm SD & $20.73 \pm 1.53$ & $30.04 \pm * 3.36$ & $23.99 \pm 3.17$ & $27.62 \pm 5.08$ \\
\hline & $\mathrm{P}$ & & 0.012 & 0.056 & 0.079 \\
\hline \multirow{2}{*}{ ALT (U/I) } & Mean \pm SD & $22.06 \pm 4.40$ & $32.97 * \pm 2.06$ & $30.59 \pm 0.83$ & $34.35 * \pm 40.75$ \\
\hline & $\mathrm{P}$ & & $>0.001$ & 0.921 & $>0.001$ \\
\hline \multirow{2}{*}{$\operatorname{ALP}(\mathbf{U} / \mathbf{l})$} & Mean \pm SD & $110.28 \pm 18.38$ & $235.26 \pm 44.83$ & $192.99 \pm 38.99$ & $130.97 \pm 0.83$ \\
\hline & $\mathrm{P}$ & & $>0.001$ & 0.013 & 0.017 \\
\hline
\end{tabular}

* The mean difference is significant at the 0.050 level

AST: Aspartate aminotransferase; ALT: Alanine aminotransferase; ALP: Alkaline phosphatase

\section{Discussion}

According to our results, simultaneous exposure to noise and styrene could result elevated liver enzymes in blood serum of experimental animals. Exposure to noise in the workplace may be accompanied by chemical solvents such as styrene. Although workplacerelated noise exposure is considered as a major reason of stress, there are also evidences showing interaction between certain chemicals and noise on organ function (25). However, to our knowledge, no other study have attempted to investigate the interaction of noise and styrene on liver enzymes.
Since weight is considered as one of the major toxicological parameters, the evaluation of organ weights in toxicology studies is an integral component for medical assessments. The Society of Toxicologic Pathology (STP) has provided recommendations for weighing organs in general toxicology studies lasting from 7 days to 1 year (26). Results of the present study indicated a significant decrease in liver/body weight ratio in the noise exposure group. The present study showed that body weight did not significantly change by exposure to noise and/or styrene for 8 hours/day and 14 days. In addition, liver 
weight in experimental groups had no significant difference compared to control group $(\mathrm{P}>0.999)$, which agrees with the Monsefi research that indicated noise exposure had no effect on body and liver weights (27). Our results did not match with those from Dehghani et al. that showed a significant reduction in liver weight compared to control group (8), which could be due to different frequency range of exposed noise, duration of exposers and also the age and primary weight of animals between two studies. On the other hand, Aravind et al. observed body weight loss after 20-day $100 \mathrm{~dB}$ white noise exposure (28). Results of the present study indicated a significant decrease in liver/body weight ratio in the noise exposure group, while conversely, Jafari reported that expressed noise had no effect on rats' weight exposed to a broad band noise (0.7-5.7 khz) at $100 \mathrm{~dB}(25)$.

Every organ can elicit a specific pattern of enzyme release when exposed to a stimulus, which remains not elucidated. Specifically, above-normal plasma enzyme activities are considered as diagnostic features for several diseases. The results showed that liver enzymes were more sensitive to noise alone than other intended pollutants; noise exposure led to significant increase in the concentration of ALP, AST and ALT in serum. We also found a significant relationship between serum ALP and ALT level and co-exposure to noise and styrene, and that exposure to styrene significantly reduced ALP compered to control group. In the study performed by Perez et al. on workers who were occupationally exposed to aromatic hydrocarbons in a petrochemical plant, the level of liver transaminases was significantly higher in the case group than the control group (29). Also, Ghaderi et al. have shown that exposure to noise stress can decrease serum ALT levels, which implies damaging effects of noise stress on liver function (30). Recently metabolic stress theories have focused on the formation of reactive oxygen species (ROS) evoked by excessive noise stimulation, pursued by activation of apoptosis signaling pathways to cell death (25). Overproduction of ROS results in oxidative stress, a state in which tissue and cellular redox balance is altered towards a more oxidizing environment (31). ROS lead to a cumulative damage to protein, lipids, DNA, carbohydrates, and membranes. The primary function of antioxidative defenses is suppressing the generation of ROS, scavenging them besides repairing and promoting reconstitution of damage, and inducing the expression of antioxidant proteins and enzymes (32, 33). The resultant liver injury was characterized by hepatomegaly and accompanied by increased activities of AST and ALT enzymes (34). According to results, it can be noted that ALT was more sensitive to liver destructive factors than AST. In ischemic or toxic liver injury, AST levels usually peak before those of ALT because of the enzyme's peculiar intralobular distribution $(35,36)$.

In this study we found that exposure to noise $(100 \mathrm{~dB})$ increased the levels of hepatic enzymes, although exposing to styrene did not affect serum AST and ALT levels in rats. Pool and Orono's studied workers occupationally exposed to mixed organic solvents in the petrochemical industry and showed that there were no statistically significant differences in the levels of hepatic enzymes compared to the control group (37). Also Todd et al. in their health survey on footwear factory workers in Thailand found that exposure to complex mixture of organic solvents did not have any toxic effect on liver (38). Also in another study on workers exposed to a mixture of organic solvents in shoe repair work, no differences in the hepatic enzymes level between the experimental and control groups were reported (39). Liver works as a detoxification unit and its tissue contains lipid. Most of serum ALP is synthetized in liver and high concentration of ALP in blood could be a result of liver dysfunction (40). In our study, we showed that co-exposure to styrene and noise for 14 days could increase the liver enzymes (ALT, AST and ALP), whereas there was no statistically significant relationship between exposure groups and control. Here, we additionally 
demonstrated that in vivo exposure to physical and chemical stress affected the enzymes tested in our study differentially. Therefore, the data obtained would suggest that the release of hepatic enzymes might be directly related to the onset of oxidant stress in the liver.

\section{Conclusion}

Following simultaneous exposure to noise and styrene, the ALT and ALP concentration in blood were increased compared to control group. Some occupational physical stressors such as intensive loud noise generate ROS that break endogenous antioxidant defense of the body and damage cellular structures. It can be said that noise stress produces free radicals followed by antioxidant proliferation and lipid peroxidation. In this study did not find any significant synergistic interaction between noise and styrene and the level of liver enzymes in blood, and there was just additive effect between noise and styrene on increasing ALP.

Liver function tests (AST, ALT and ALP) are suitable for the diagnosis of early stages of liver dysfunction due to occupational exposures, which are inexpensive, accessible and nonaggressive.

\section{Acknowledgements}

The present study is a result of Mrs. Mahsa Tehrani MS thesis approved by research deputy of Tarbiyat Modares University. The authors would also like to show gratitude to the Dr. M. Faridan, and are grateful to Mrs. Arezoomandan and Mr. Ahmdi for their comments.

Conflict of interest: None declared

\section{References}

1. Basner M, Babisch W, Davis A, Brink M, Clark $\mathrm{Ch}$, Janssen $\mathrm{S}$, et al. Auditory and nonauditory effects of noise on health. Lancet 2014; 383(9925):1325-32.
2. Hughes RW, Jones DM. Indispensable benefits and unavoidable costs of unattended sound for cognitive functioning. Noise Health 2003; 6(21):63-76.

3. Kopke RD, Weisskopf PA, Boone JL, Jackson RL, Wester DC, Hoffer ME, et al. Reduction of noise-induced hearing loss using L-NAC and salicylate in the chinchilla. Hear Res 2000; 149(1-2):138-46.

4. Harkness JE, Wagner JE. Biology and medicine of rabbits and rodents. $4^{\text {th }}$ ed. Philadelphia, United States: Lippincott Williams and Wilkins; 1995.

5. Singhal S, Yadav B, Hashmi SF, Muzammil M. Effects of workplace noise on blood pressure and heart rate. Biomedical Research 2009; 20(2):122-6.

6. Haase GM, Prasad KN, Cole WC, BaggettStrehlau JM, Wyatt SE. Antioxidant micronutrient impact on hearing disorders: concept, rationale, and evidence. Am J Otolaryngol 2011; 32(1):55-61.

7. Demirel R, Mollaoğlu H, Yeşilyurt H, Üçok K, Ayçiçek A, Akkaya M, et al. Noise induces oxidative stress in rat. European Journal of General Medicine 2009; 6(1):20-24.

8. Dehghani A, Ranjbariyan M, Khavanin A, Rezazade-Azari M, Vosooghi Sh. Exposure to noise pollution and its effect on oxidant and antioxidant parameters in blood and liver tissue of rat. Zahedan Journal of Research in Medical Sciences 2013; 15(5):13-7.

9. Xue L, Zhang D, Yibulayin X, Wang T, Shou $\mathrm{X}$. Effects of high frequency noise on female rat's multi-organ histology. Noise Health 2014; 16(71):213-7.

10. Agency for Toxic Substances and Disease Registry. Toxicological profile for styrene. Department of Health and Human Services, Public Health Service, Division of Toxicology and Environmental Medicine/Applied Toxicology Branch. Atlanta, Georgia: Agency for Toxic Substances and Disease Registry; $2010 . \quad$ Available from: https://www.atsdr.cdc.gov/toxprofiles/tp53.pdf

11. World Health Organization. International Programme on Chemical Safety (IPCS). Switzerland, Geneve: World Health Organization; 1998. Available from: http://www.who.int/ipcs/en/

12. LaDou J. Current occupational and environmental medicine: (Lange Medical Books). $4^{\text {th }}$ ed. New York City, United States: McGraw Hill Education; 2006. P.499.

13. Lundgvist G, Flodin U, Axelson O. A casecontrol study of fatty liver disease and organic solvent exposure. Am J Ind Med 1999; 35(2):132-6. 
14. Kelly TJ, Mukund R, Spicer ChW, Pollack AJ. Concentrations and transformations of hazardous air pollutants. Environ Sci Technol 1994; 28(8):378A-7A.

15. Adamson AW, Gast AP. Physical chemistry of surfaces. $6^{\text {th }}$ ed. Hoboken, New Jersey, United States: John Wiley \& Sons, Inc; 1997. P.808.

16. World Health Organization. IARC monographs on the evaluation of carcinogenic risks to humans. International Agency for Research on Cancer. Some traditional herbal medicines,some mycotoxins, naphthalene and styrene (Vol 82). Geneva: International Agency for Research on Cancer; 2002 Feb. 601p.

17. Eaton DL, Gilbert SG. Principles of toxicology. In: Klaassen $\mathrm{CD}$, Amdur MO, Doull J editors. Casarett \& doull's toxicology: the basic sciences of poisons. 5th ed. New York City, United States: McGraw Hill Education; 1996; P.13-33

18. Cary R, Clarke S, Delic J. Effects of combined exposure to noise and toxic substances--critical review of the literature. Ann Occup Hyg 1997; 41(4):455-65.

19. Matés JM, Pérez-Gómez C, Núñez de Castro I. Antioxidant enzymes and human diseases. Clin Biochem 1999; 32(8):595-603.

20. National Research Council (US) Committee for the Update of the Guide for the Care and Use of Laboratory Animals. Guide for the care and use of laboratory animals. $8^{\text {th }}$ ed. Washington (DC), United States: National Academies Press; 2011. 246p.

21. De Piceis Polver $\mathrm{P}$, Fenoglio $\mathrm{C}$, Nano $\mathrm{R}$, Coccini $\mathrm{T}$, Bertone V, Vaccarone $\mathrm{R}$, et al. Styrene hepatotoxicity in rats treated by inhalationor intraperitoneally: a structural investigation. Histol Histopathol 2003; 18(1):49-54.

22. Lataye R, Campo P, Loquet G. Combined effects of noise and styrene exposure on hearing function in the rat. Hear Res 2000; 139(1-2):86-96.

23. Office of Animal Resources Institutional Animal Care and Use Committee. IACUC Guidelines: Anesthesia. [Internet] 2017 [updated 2016 July 13]. Available from: https://animal.research.uiowa.edu/iacucguidelines-anesthesia

24. Kanter M, Coskun O, Budancamanak M. Hepatoprotective effects of Nigella sativa $\mathrm{L}$ and Urtica dioica L on lipid peroxidation, antioxidant enzyme systems and liver enzymes in carbon tetrachloride-treated rats. World $\mathrm{J}$ Gastroenterol 2005; 11(42):6684-8.

25. Jafari MJ, Dehghani A, Khavanin A, AzariReza-Zade M, Dadashpourahangar A. The impact of noise and formaldehyde exposure on oxidative stress indices in blood and liver tissue of rat. International journal of occupational hygiene 2014; 6(2):61-7.

26. Sellers RS, Morton D, Michael B, Roome N, Johnson JK, Yano BL, et al. Society of toxicologic pathology position paper: organ weight recommendations for toxicology studies. Toxicol Pathol 2007; 35(5):751-5.

27. Monsefi M, Bahoddini A, Nazemi S, Dehghani GA. Effects of noise exposure on the volume of adrenal gland and serum levels of cortisol in rat. Iran J Med Sci 2006; 31(1):5-8.

28. Aravind KN, Mathangi DC, Namasivayam A. Noise induced changes in free radical scavenging enzymes in the blood and brain of albino rats. Med Sci Res 1998; 26(12):811-2.

29. Pérez CA, Bosia JD, Cantore MS, Chiera A, Cocozzella DR, Adrover RE, et al. Liver damage in workers exposed to hydrocarbons. Gastroenterol Hepatol 2006; 29(6):334-7.

30. Ghaderi P, Sohrabi MR, Ahmadi R, Alishahi M. Effects of noise stress on liver function. Paper presented at: The International Conference of Social Science Medicine and Nursing; 2015 June 5-6; Istanbul, Turkey.

31. Medina J, Moreno-Otero R. Pathophysiological basis for antioxidant therapy in chronic liver disease. Drugs 2005; 65(17):2445-61.

32. Naik SR, Thakare VN, Patil SR. Protective effect of curcumin on experimentally induced inflammation, hepatotoxicity and cardiotoxicity in rats: evidence of its antioxidant property. Exp Toxicol Pathol 2011; 63(5):419-31.

33. Tiwari AK. Imbalance in antioxidant defence and human diseases: multiple approach of natural antioxidants therapy. Curr Sci 2001; 81(9):1179-87.

34. Abreu IC, Guerra JF, Pereira RR, Silva M, Lima WG, Silva ME, et al. Hypercholesterolemic diet induces hepatic steatosis and alterations in mRNA expression of NADPH oxidase in rat livers. Arq Bras Endocrinol Metabol 2014; 58(3):251-9.

35. Seeto RK, Fenn B, Rockey DC. Ischemic hepatitis: clinical presentation and pathogenesis. Am J Med 2000; 109(2):109-13.

36. Singer AJ, Carracio TR, Mofenson HC. The temporal profile of increased transaminase levels in patients with acetaminophen-induced liver dysfunction. Ann Emerg Med 1995; 26(1):49-53.

37. Fernández-D'Pool J, Oroño-Osorio A. Pool F, Orono A. Liver function of workers occupationally exposed to mixed organic solvents in a petrochemical industry. Invest Clin 2001; 42(2):87-106. 
38. Todd L, Puangthongthub ST, Mottus K, Mihlan G, Wing S. Health survey of workers exposed to mixed solvent and ergonomic hazards in footwear and equipment factory workers in Thailand. Ann Occup Hyg 2008; 52(3):195-205.

39. Uuksulainen SO, Heikkila PR, Olkinuora PS,
Kiilunen M. Self reported occupational health hazards and measured exposures to airborne impurities and noise in shoe repair work. Int $\mathbf{J}$ Occup Environ Health 2002; 8(4):320-7.

40. Giannini EG, Testa R, Savarino V. Liver enzyme alteration: a guide for clinicians. CMAJ 2005; 172(3):367-79. 